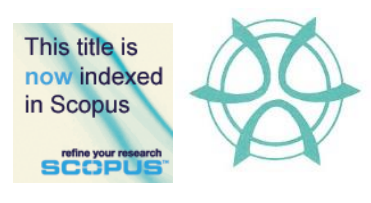

PLANNING MALAYSIA:

Journal of the Malaysian Institute of Planners

VOLUME 16 ISSUE 3 (2018) Page 171 - 181

\title{
PREFERENCE OF RESIDENTIAL TYPOLOGIES OF URBAN MALAYSIANS
}

\author{
Lim Poh $\operatorname{Im}^{1} \&$ Chang Yun Fah ${ }^{2}$ \\ Faculty of Engineering \& Science \\ UNIVERSITI TUNKU ABDUL RAHMAN, MALAYSIA
}

\begin{abstract}
This paper seeks to understand patterns of residential preferences of urban Malaysians when seeking to purchase residential properties. Data was gathered through sampling surveys targeting potential house buyers in property fairs in three urban centres in Malaysia, namely Kuala Lumpur, Georgetown and Johor Bahru. Results highlighted significant presence of young purchasers and firsttime buyers; majority seeking to purchase properties priced RM600,000 and below; and taking very long tenure to finance the properties. Double-storey terrace and condominium, accumulatively garnered higher popular choice, but both fell short of 'Most Preferred' category. Factor analysis discovered that overall landed properties fared better than multi-storey buildings as preferred residential typology across the board regardless of socio-economic backgrounds. Family situation and circumstance, referring to marital status, number of family member, and whether they previously owned a property, were found to be the most crucial factors governing their choice on the preferred type of residential properties.
\end{abstract}

Keywords: housing typology, housing preference house choice, residential typologies, family factors in housing, landed housing, multi-storey housing 
Lim Poh Im \& Chang Yun Fah

Preference of Residential Typologies of Urban Malaysians

\section{INTRODUCTION}

The research on housing or homeownership can be approached from different angles and subject to diverse influencing factors. Home ownership is a result of many determinants, including housing characteristics (house types and property types), employment and income trends, and socio-cultural and demographic descriptors. This paper seeks to understand preferences in types of residential properties, and factors determining the decisions in choosing them, based on feedback from potential house-buyers in three urban centres in Malaysia, namely Kuala Lumpur, Georgetown and Johor Bahru. These three cities were chosen as they represent the three largest cities in Malaysia with the highest concentration of urban population, highest transaction of properties and most affluent housing markets and high living costs. The typologies of residential properties included in this paper are based on commonly found housing typologies in Malaysia. Factors influencing choices of residential properties include profile of buyer, i.e. investors vs. genuine buyers and first time home buyers; socio-marital background, e.g. age, gender, family situation, occupation and other factors related to finance arrangement and payment methods.

\section{LITERATURE REVIEW}

\section{Residential Building Typology and Character in Malaysian Cities}

The definition of housing typology itself can be referred to the classification of residential buildings, according to its association with physical composition, intensity of development and degree of formality. There are many types of residential properties in Malaysia. In this study, the categorisation is based on the most commonly found housing typologies in Malaysian cities using the Malaysian National Property Information (NAPIC)'s house price index categorisation as a basis. NAPIC categorised the residential properties into only four, namely terrace, high-rise, semi-detached and detached house. For this study, these were further divided them into townhouse, apartment, condominium, flat, shop-house/shop-apartment, terrace house, semi-detached house and detached house/bungalow, for a more meaningful understanding on the commonly found residential typologies in Malaysian cities.

The diversity in the residential typologies in Malaysia cities is a combined result of historical trends, contemporary market forces and the regulatory demands. The colonial heritage in the past, which merged with local traditional forms of housing, resulted in housing types of 'terrace house', 'shophouse' and 'bungalows' (Ju \& Omar, 2011). 'Shop-house' for instance, is a hybrid residential-commercial typology, traditionally found in South-east Asian colonial cities. 'Terrace house' can be taken as the most economic type of landed property, while 'semi-detached' type has bigger private compounds, but do not have the luxurious amount of open spaces like the 'bungalow'. Another type of 
landed property is townhouse, which is an individual stratified unit with separate entrances for the upper and lower units.

Other than this, the high-density and multi-storey types of housing, such as 'apartment', 'condominium' and 'flat' are more popularly found in urban centres in Malaysia. The housing landscape of Malaysian cities reflects the increased demand in urban population and the regulatory regimes governing urban planning and housing development. Planning controls restrict the amount of land available for housing, and determine the density as well as the types of development activity of the location or zonation. Planning standards specifying the allowable units per acre or in plot ratio, building height, land set-backs, amount of land for open space and amenities, and in the cases of low-cost and affordable units, the unit size. As a result, high-density development can be synonymous to the high-rise typologies, including apartment, condominium and flat, with densities of 60 to 128 units per acre. Low-rise units refer to cluster, terrace and townhouse (20 to 35 units per acre), while detached, semi-detached and bungalow houses can have very low density, as low as 15 units per acre.

\section{Factors Influencing Preferences on Types of Residential Buildings}

Research on residential housing choice and preference are wide and multifaceted. There has been a tradition of explaining housing preference based on homebuyer demographics such as age, household composition, income, and current housing situation (Rossi \& Weber, 2010). Empirical studies relating housing choice and socio-demographic backgrounds have shown that home ownership is strongly related to stages in the life cycle (Clark \& Onaka, 1983), the presence of children (Coulson, 1999; Goodman, 1990; Haurin \& Kamara, 1992) and employment types and location (Levine, 2007)

In a study of factors affecting buying behaviour of apartment in Amman Jordan, significant constructs such as aesthetic, economic, marketing, geographic, and social factors were found. The study concluded that there were significant differences in terms of respondents' gender and age, but no significant differences according to the marital status or educational level (Haddad, Judeh, \& Haddad, 2011). In a study on house purchase intention of consumers in Kota Kinabalu, Malaysia, it was found that house features, financing, distance, environment and superstition-numbers have significant positive relationships with house purchase intention (Chia, Harun, Kassim, Martin, \& Kepal, 2016).

Indeed, house preferences are not only influenced by social-demographic descriptors, but equally important are buyers' intentions and their finance situations. In understanding reasons of homeownership factors in Malaysia, Tan (2009) uncovered six factors, namely local amenities and social capital investment, properties maintenance and improvement, length of tenure, children's educational needs and financial benefits in understanding buyers' motivation as considerations in buying homes in Malaysia. 
Lim Poh Im \& Chang Yun Fah

Preference of Residential Typologies of Urban Malaysians

In a study of factors affecting the purchase decision of investors in the residential property market in Malaysia, it was revealed that locational, financial and structural factors affect property investors in making their purchases (Tan, 2012), while Kohler (2013) revealed that investors generally prefer smaller properties especially apartments and flats as these properties have always been more popular among tenants. In identifying drivers behind housing preferences of first-time home buyers, Reed and Mills (2006) confirmed that "financial" issues accounted for approximately 30 percent of the actual decision by first-time buyers to purchase housing, while decisions relating to the timing and choice were dependent on "site-specific" factors.

Most literature found relate housing preferences to the sociodemographic attributes and reasons behind certain choices were made, but seldom correlate to the different housing typologies. Only one finding from a recent study of young Malaysians in Subang Jaya, Selangor, Malaysia which revealed that young urbanites preferred landed housing with more bedrooms compared to high-rise housing. They preferred to live in urban area so as to be close to workplace and services. They targeted high priced houses despite facing affordability issues (Ling, Mansur, \& Musthafa, 2016).

\section{METHODOLOGY}

\section{Sampling and Questionnaire}

Primary data using a face-to-face convenient sampling survey was conducted in three major Malaysian cities, namely Kuala Lumpur in the central region of Peninsular Malaysia, Penang in the northern region, and Johor Bahru in the southern part of Peninsular Malaysia. The surveys were conducted at five major property fairs in year 2016. These property fairs are Malaysia Property Expo (MAPEX), The Star Property Fairs, and Malaysia Secondary Property Exhibition (MASPEX). A total of 1015 valid samples were analysed. The survey targeted visitors to the property fairs. The survey questionnaire included 66 questions concerning respondents' socio-demographic backgrounds, current family and living conditions, payment and financial arrangements, and housing type preference. For this paper, 27 questions grouped under the following categories were analysed:

- Respondents' socio-demographic data: marital status, living condition, number of family member, occupation, education level, age, gender, ethnicity, religion, household income, currently own any property.

- Preferred type of house: flat, apartment, townhouse, condominium, shophouse, single storey terrace, double storey terrace, semi-detached, and bungalow.

- Purpose of purchase: payment method, loan tenure, percentage of income for property, house price, floor size, etc. 
PLANNING MALAYSIA

Journal of the Malaysia Institute of Planners (2018)

All questions related to house type preference were measured using a five-point Likert Scale and respondents were asked to state the level of their agreement on preferred house types.

\section{Analytical Method}

Statistical analysis was carried out using the IBM Statistical Package for the Social Science (SPSS) for Windows version 22.0. Exploratory factor analysis was used to investigate the relationships between the factors and to identify the unspoken concerns of the respondents behind purchasing a type of residential property. Principal Component was used as an extraction method and orthogonal Varimax rotation to optimize the results.

\section{General Characteristics of the Respondents}

Referring to Table 2, in terms of age group, majority of respondents $(77.5 \%)$ consists of youth aged between 20 to 39 years-old, with 58.3\% males and $41.7 \%$ females. For ethnic background, 67.6\% were Chinese, followed by Malay (26.3\%) and Indian (4.8\%). Majority of the respondents were from higher income occupations i.e. 'businessmen, managerial and professionals' (78.2\%) and they were mostly highly educated.

'Family and living situation' data shows that $33.8 \%$ of respondents were singles who live with their parents, singles who live with friends $(17.7 \%)$, while married couples with and without children consist of $34.5 \%$. On marital status, a significant portion was singles $(53.9 \%)$ as opposed to $46.1 \%$ married. Small households with one or two persons consist of a whopping $43.5 \%$ of respondents, compared to households with three to four persons (36.7\%); while larger households with five and six members only occupied $19.8 \%$.

With regard to main intention to own the property, majority purchased mainly for own stay (59.2\%) as opposed to $40.8 \%$ for investment. Slightly more than half of the potential buyers have owned a property (59.1\%) while equally significant numbers (40.9\%) were first-time buyers. On the types of property, whether they prefer 'new property', 'sub-sale' or 'do not mind either', about half of the respondents choose 'new property' while a significant portion (45\%) did not mind both. In terms of unit size preference, majority $(87.2 \%)$ choose sizes between 750 to 2000 square feet.

Majority or $74.5 \%$ of the potential purchasers indicated they prefer house priced below RM600,000, out of which $45.1 \%$ were not willing to pay higher than RM400,000. This was understandable judging from the same data which pointed out that a significant number or $55.6 \%$ of the respondents has household income of RM6,000 and below. In a property survey data from Q3 2016, the average house price in Kuala Lumpur was around RM772,126 (NAPIC, 2016) and the average costs of a 1000 sq. ft. apartment in a typical Malaysian city was between RM516,700 and RM1.2 million (Numbeo, 2017) Our data revealed that 
Lim Poh Im \& Chang Yun Fah

Preference of Residential Typologies of Urban Malaysian

the price that most people were willing or could afford to pay is much lower than the average prices of housing in the market. Under such circumstances, it was not surprising that nearly all respondents have to get a mortgage from bank (94.3\%), and more than $45 \%$ respondents allocate more than $30 \%$ of their income to finance the property, and commit to long-term mortgage tenure, whereby $63.5 \%$ have to take a loan longer than 26 years, and $35.7 \%$ have to commit to a loan period longer than 30 years.

Table 2: Respondents' socio-demographic profile

\begin{tabular}{|c|c|c|c|}
\hline Variables & $\%$ & Variables & $\%$ \\
\hline \multicolumn{2}{|l|}{ Age } & \multicolumn{2}{|c|}{ Currently own any property } \\
\hline 20 - 29 years old & 22.1 & Owned a property & 59.1 \\
\hline 30 - 39 years old & 55.4 & First time buyers & 40.9 \\
\hline $40-49$ years old & 14.7 & \multicolumn{2}{|c|}{ Preferred type of property } \\
\hline 50 - 59 years old & 3.6 & New property & 49.3 \\
\hline Above 60 years old & 4.2 & Sub-sale & 5.7 \\
\hline \multicolumn{2}{|l|}{ Gender } & Either & 45.0 \\
\hline Male & 58.3 & \multicolumn{2}{|c|}{ Preferred floor size (Sq. Ft.) } \\
\hline Female & 41.7 & Below 750sf & 6.7 \\
\hline \multicolumn{2}{|c|}{ Occupation } & Below 1,000sf & 25.6 \\
\hline No permanent employment & 4.8 & Below 1,250sf & 27.7 \\
\hline Retiree & 2.2 & Below 2,000sf & 33.9 \\
\hline Labourer \& administrative & 14.9 & Above $2,000 \mathrm{sf}$ & 6.1 \\
\hline Businessmen & 21.7 & \multicolumn{2}{|l|}{ Preferred house price } \\
\hline Managerial & 15.7 & Below RM200k (USD46,087) & 8.6 \\
\hline Professional & 40.8 & $\begin{array}{l}\text { RM200,001 to RM400,000 } \\
\text { (USD46,088 to USD92,174) }\end{array}$ & 36.5 \\
\hline \multicolumn{2}{|c|}{ Education Level } & $\begin{array}{l}\text { RM400,001 to RM600,000 } \\
\text { (USD92,175 to USD138,261) }\end{array}$ & 29.4 \\
\hline Lower secondary and below & 3.4 & $\begin{array}{l}\text { RM600,001 to RM800,000 } \\
\text { (USD138,261 to USD184,348) }\end{array}$ & 16.9 \\
\hline High school & 14.8 & $\begin{array}{l}\text { RM800,000 to RM1 million } \\
\text { (USD184,349 to 230,435) }\end{array}$ & 4.7 \\
\hline Certificate \& Diploma & 23.8 & $\begin{array}{l}\text { Above RM1 million } \\
\text { (Above USD230,435) }\end{array}$ & 3.9 \\
\hline Bachelor degree & 46.2 & \multicolumn{2}{|c|}{ Preferred payment method } \\
\hline Postgraduate degree & 11.7 & Cash & 5.7 \\
\hline \multicolumn{2}{|c|}{ Living Condition } & Cash \& Mortgage & 94.3 \\
\hline Single with parents & 33.8 & \multicolumn{2}{|l|}{ Household Income } \\
\hline Single staying alone & 9.5 & RM6000 (USD1,382) \& below & 55.6 \\
\hline Single staying with friends & 17.7 & $\begin{array}{c}\text { RM6001 - RM10,000(USD1,382 to } \\
\text { USD2,304) }\end{array}$ & 25.0 \\
\hline Married without children & 19.0 & $\begin{array}{l}\text { RM10,001 - RM14,000 } \\
\text { (USD2,304 - USD3,226) }\end{array}$ & 14.1 \\
\hline Married with children & 15.5 & Above RM14,001 (USD3,226) & 5.3 \\
\hline Others & 4.5 & $\begin{array}{c}\text { Willing to allocate percentage of inc } \\
\text { the property }\end{array}$ & finan \\
\hline
\end{tabular}


PLANNING MALAYSIA

Journal of the Malaysia Institute of Planners (2018)

\begin{tabular}{cc|cc}
\hline \multicolumn{2}{c|}{ Marital Status } & Below 20\% & 18.6 \\
\hline Single & 53.9 & $20.1 \%-30 \%$ & 36.3 \\
\hline Married & 46.1 & $30.1 \%-40 \%$ & 21.4 \\
\hline Number of Family Member & $40.1 \%-50 \%$ & 15.5 \\
\hline One person & 33.8 & Above 50\% & 8.2 \\
\hline Two persons & 9.7 & Preferred loan Tenure & 6.6 \\
\hline Three persons & 17.7 & Below 10 years & 17.8 \\
\hline Four persons & 19.0 & $11-15$ years & 12.1 \\
\hline Five persons & 15.5 & $16-25$ years & 27.8 \\
\hline Six persons & 4.3 & $26-30$ years & 35.7 \\
\hline Purpose of Purchase & & Above 30 years & \\
\hline Own stay & 59.2 & &
\end{tabular}

Source: Own survey data

\section{RESULTS AND DISCUSSION}

\section{Respondents' Preferences on Various Types of Property}

Respondents were asked to state their preferences on the types of residential properties in 5-level Likert Scale ranged from Least Preferred to Most preferred. Among various types of property, flat and shop-house have the lowest popularity where $69.9 \%$ and $65.6 \%$ of the respondents chose 'Least Preferred' and 'Not likely' respectively (Table 3 ). Townhouse was also not favoured as it manly occupied the lower tiers of the preference scale.

Accumulatively, double-storey terrace and condominium seemed to be quite popular among the buyers, with $82.3 \%$ and $82.1 \%$ potential purchasers chose "Most Preferred', 'I Can Consider' or 'Do Not Mind' respectively. In particular, double-storey terrace and semi-detached types scored the highest in 'Most preferred' category, with $25.9 \%$ and $24.8 \%$ respectively. Interestingly, condominium scored the highest in 'I can consider' category with $36.3 \%$ compared to $22.8 \%$ in the 'Most preferred' category. This is similar to doublestorey terrace, where more respondents chose 'I Can Consider' (34.7\%).

As for apartment and single-storey terrace, data seemed to suggest that there was a mixed reaction and no strong preference on either extreme ends, with higher percentage of respondents concentrates in the middle, choosing 'I don't mind' and 'I can consider'. For bungalow type, the preference level seemed to spread quite evenly between those who prefer and not prefer. This suggests that as much as there were people who prefer bungalow, there were those who do not fancy them. This may be attributed to affordability concerns. 
Lim Poh Im \& Chang Yun Fah

Preference of Residential Typologies of Urban Malaysians

Table 3: Heat map indicates preference level on different types of property

\begin{tabular}{|c|c|c|c|c|c|}
\hline & & & & & \\
\hline & $\begin{array}{c}\text { Least } \\
\text { Preferred }\end{array}$ & $\begin{array}{l}\text { Not Likely } \\
\text { to Choose }\end{array}$ & $\begin{array}{l}\text { I Don't } \\
\text { Mind }\end{array}$ & $\begin{array}{c}\text { I Can } \\
\text { Consider }\end{array}$ & $\begin{array}{c}\text { Most } \\
\text { Preferred }\end{array}$ \\
\hline Townhouse & $33.7 \%$ & $20.8 \%$ & $24.9 \%$ & $16.9 \%$ & $3.6 \%$ \\
\hline Apartment & $18.0 \%$ & $17.0 \%$ & $29.8 \%$ & $24.9 \%$ & $10.3 \%$ \\
\hline Condominium & $8.2 \%$ & $9.7 \%$ & $23.2 \%$ & $36.1 \%$ & $22.8 \%$ \\
\hline Flat & \begin{tabular}{|l|}
$41.6 \%$ \\
\end{tabular} & $28.3 \%$ & $18.7 \%$ & $8.9 \%$ & $2.5 \%$ \\
\hline Shop-house & $41.5 \%$ & $24.1 \%$ & $17.7 \%$ & $11.8 \%$ & $4.9 \%$ \\
\hline Terrace Single & $17.3 \%$ & $14.3 \%$ & $25.5 \%$ & $28.4 \%$ & $14.6 \%$ \\
\hline Terrace Double & $8.1 \%$ & $9.7 \%$ & $21.7 \%$ & $34.7 \%$ & $25.9 \%$ \\
\hline Semi D & $12.6 \%$ & $14.0 \%$ & $22.8 \%$ & $25.7 \%$ & $24.9 \%$ \\
\hline Bungalow & $20.1 \%$ & $19.4 \%$ & $21.0 \%$ & $18.9 \%$ & $20.5 \%$ \\
\hline
\end{tabular}

Source: Own survey data

Based on the heat map in Table 3, it is observed that landed properties are generally more popular than multi-storey properties, except for condominium. This coincides to an earlier study of young people living in Subang Jaya, Kuala Lumpur, which pointed that most respondents still preferred landed properties albeit a generous supply of high-rise housing in that area. (Ling et al., 2016). This observation is re-examined using factor analysis in the next section.

\section{Unspoken Concerns of Potential Buyers}

Exploratory factor analyses (EFA) were employed to investigate the hidden construct of the factors. Note that 'living condition' was excluded from EFA because it had perfect relationship $(r=1.0)$ with the number of family member. This suggests that, for example, one person households equate singles either staying alone, with friends or with family members; whereas households with more than one person refer to 'married couples with or without children'. EFA with principal components extraction method and Equamax rotation resulted in nine components (Table 4) that had eigenvalues contributed accumulative $58.57 \%$ of variance explained and its KMO measure of sampling adequacy is 0.673 (p-value $<0.001$ ).

The most important component, named as 'Preference on landed property' accounted for $11.56 \%$ of the total variance explained or the total information. This finding confirmed to an earlier finding by Ling et al. (2016). This component has positive relation to factors such as single-storey terrace, double storey terrace, semi-detached and bungalow. The second most important component represents 'Family Situation' accounted for 9.82\% of the total information that includes factors such as number of family member, marital status and whether the respondents owned a property. This suggests that married 
PLANNING MALAYSIA

Journal of the Malaysia Institute of Planners (2018)

respondents who owned property, has more family member, and hence their family size is larger. The 'family Situation' factor can relate to the importance of household composition mentioned by Rossi and Weber (2010), and to certain extent, the effects of life cycle as discussed by Clark and Onaka (1983).

Table 4: Nine components resulted from factor analysis with Equamax rotation (only coefficients relevant to the component are indicated)

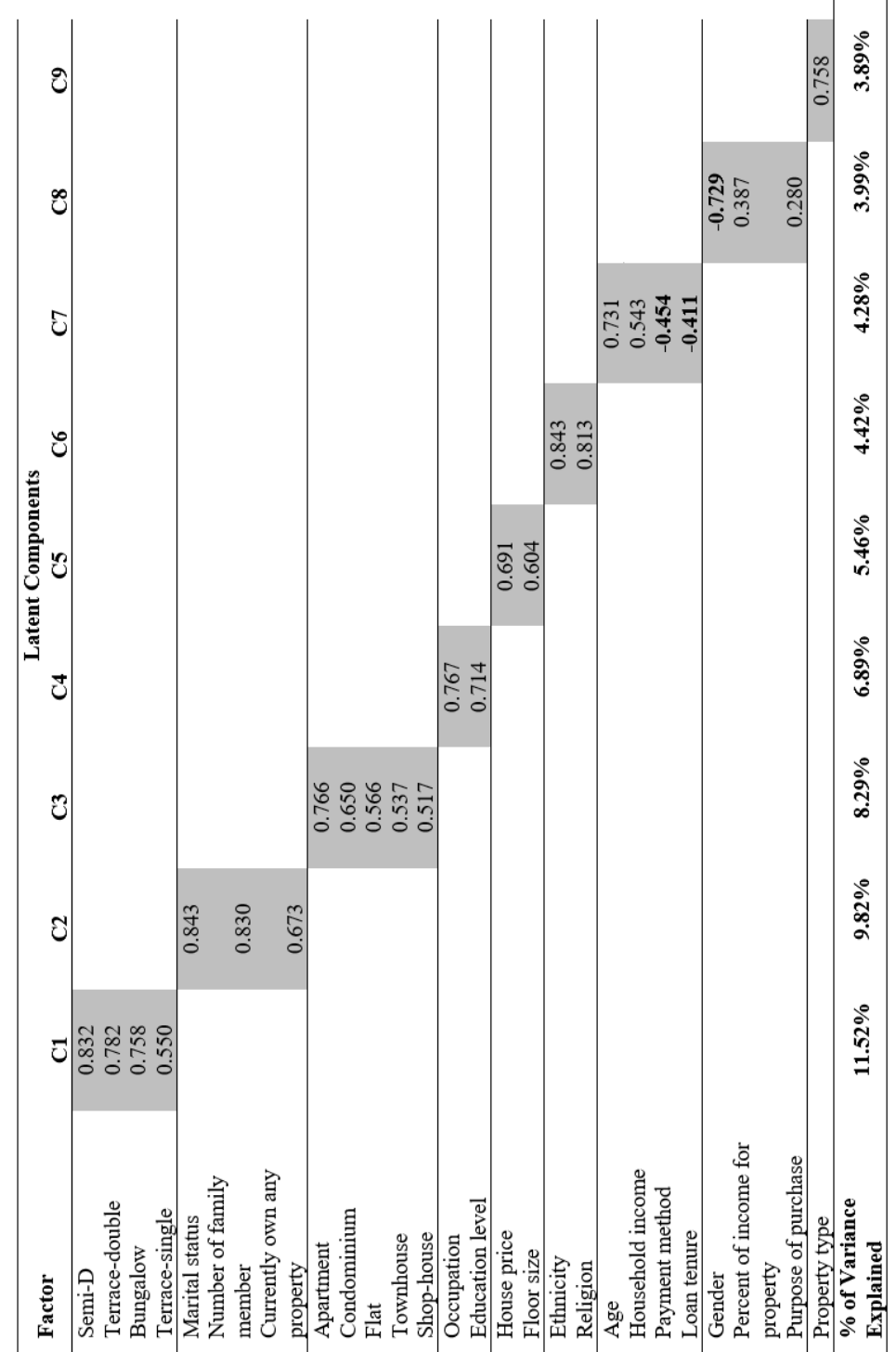

Note: C1: Preference on landed property, C2: Family situation, C3: Multi storey property, C4: Occupation \& education, C5: Preferred pricing \& size, C6: Ethnic \& religion, C7: Financial arrangement, C8: Purchasing preference, C9: Property type. 
Lim Poh Im \& Chang Yun Fah

Preference of Residential Typologies of Urban Malaysians

The third component represents other types of property contributed $8.29 \%$ of the total information. This include apartment, condominium, flat, townhouse and shop-house. This result revealed that the potential house-buyers placed higher preference on landed properties than multi-storey properties. Other components are 'Occupation and Education' refer to occupation and education level of the respondents; 'Preferred Pricing and Size' (preferred house price and floor size); 'Ethnic and Religion' (ethnicity and religion of the respondents); and 'Financial Arrangement' represents respondent's age, household income, preferred loan tenure and payment method. The last two components are 'Purchasing Preference' consists of gender, purpose of purchase, and percentage of income for property, and 'Property Type'.

While most factors have positive relations with the respective hidden components, 'payment method', 'loan tenure' and 'gender' showed negative relations. The explanation could be that for example, an older house buyer with higher household income tends to get shorter loan tenure by paying with cash, and hence the 'financial arrangement' level was lower. Also, it was observed that the 'purchasing preference' was higher for male who intended to buy house for own stay will allocate higher portion of income for property.

\section{CONCLUSION}

As this study has chosen a sample population from potential buyers at property fairs, it only represents a segment of Malaysian urban population that has intentions to purchase properties. Hence the data will not be generalised to the entire population. This study has tried to discover factors leading to housing preferences and to make distinctions on the types of residential typologies most preferred by urban Malaysians. The findings confirmed the issues of mismatch between preferred house price and affordability, and high reliance on long term mortgage arrangement. It was also discovered that there were high interests among younger purchasers despite them facing financial challenges. Factor Analysis highlighted that landed property remained the most preferred choice as compared with multi-storey types regardless of respondents' backgrounds. Double-storey terrace and condominium seemed to garner higher accumulative positive preferences. In addition, our data also showed that 'family situation' was the second most important component in the factor analysis, specifically 'family size', 'marital status' and 'whether previously owned a property' were the major deciding factors. Owing to this trend, it is suggested that future housing development could devote resources to assess and match the socio-demographic profiles of potential purchasers with the types of residential property to offer. 


\section{ACKNOWLEDGEMENT}

This research was conducted under a research fund from Exploratory Research Grant Scheme (ERGS), Ministry of Higher Education (MOHE) Malaysia. Special thanks to The Star Property and Mr Michael Geh of Raine \& Horne, for their kind assistance and contribution.

\section{REFERENCES}

Chia, J., Harun, A., Mohd Kassim, A. W., Martin, D., \& Kepal, N. (2016). Understanding factors that influence house purchase among consumers in Kota Kinabalu: an application of buyer behaviour model theory. Journal of Technology Management and Business, 3(2), 94-110.

Clark, W. A. V., \& Onaka, J. L. (1983). Life cycle and housing adjustment as explanations of residential mobility. Urban Studies, 20(1), 47-57.

Coulson, N. E. (1999). Why are Hispanic and Asian-American homeownership rates so low? Immigration and other factors. Journal of Urban Economics, 45(2), 209227.

Goodman, A. C. (1990). Demographic of individual housing demand. Regional Science and Urban Economics, 20(1), 83-102.

Haurin, D. R., \& Kamara, D. (1992). The homeownership decision of female-headed households. Journal of Housing Economics, 2(4), 293-309.

Haddad, M., Judeh, M., \& Haddad, S. (2011). Factors affecting buying behaviour of an apartment: an empirical investigation in Amman Jordan. Research Journal of Applied Sciences, Engineering and Technology, 3(3), 234-239.

Ju, S. R., \& Omar, S. (2011, October). Housing typology of Modern Malaysia. 1st South East Asia Housing Forum of ARCH. October 6-7, 2011, Seoul, Korea.

Kohler, M. J. (2013). Why you should be investing your money in real estate. Retrieved from http://www.entrepreneur.com/article/228506.

Levine, J. (2007). Rethinking accessibility and jobs-housing balance. Journal of the American Planning Association, 64(2), 133-149.

Ling, O., Mansur, N. A., \& Musthafa, S. N. (2016). The housing preference of young people in Malaysian urban areas: A case study Subang Jaya, Selangor. Malaysian Journal of Society and Space, 12(7), 60-74.

Numbeo (2017). Property prices in Malaysia. Retrieved from https://www.numbeo.com/property-investment/country_result.jsp?country= Malaysia

National Property Information Centre [NAPIC] (2016). Residential property stock tables Q3 2016. Available at http://napic.jpph.gov.my/portal/key-statistics

Rossi, P. H., \& Weber, E. (2010). The social benefits of homeownership: Empirical evidence from national survey. Housing Policy Debates, 7(1), 1-35.

Reed, R., \& Mills, A. (2006). Identifying the drivers behind housing preferences of firsttime owners. Property Management, 25(3), 225-241.

Tan, T. H. (2012). Meeting first-time buyers' housing needs and preferences in greater Kuala Lumpur. Cities, 29(6), 389-396.

Tan, T. H. (2009). Home owning motivation, Malaysia. Journal of Accounting, Business and Management, 1(1), 93-112. 